ISSN 0206-5657. Вісник Львівського університету. Серія біологічна. 2021. Випуск 84. С. 33-39 Visnyk of the Lviv University. Series Biology. 2021. Issue 84. P. 33-39

\title{
БІОТЕХНОЛОГІЯ
}

УДК 579.873.1:577.181.4

https://doi.org/10.30970/vlubs.2021.84.03

\section{THE MIA MUTANTS OF STREPTOMYCES ALBUS J1074 ARE PRONE TO TRANSLATIONAL ERRORS AND SUSCEPTIBLE TO CERTAIN STRESSORS}

\author{
O. Rydkin, O. Koshla, B. Ostash
}

Ivan Franko National University of Lviv

4, Hrushevskyi St., Lviv 79005, Ukraine

*e-mail: bohdan.ostash@lnu.edu.ua

\begin{abstract}
Streptomyces albus $\mathrm{J} 1074$ has been established by us as a convenient model to study different aspects of tRNA ${ }_{\text {UAA }}^{\text {Leu }}$-dependent regulatory mechanisms, that take place in genus Streptomyces. These mechanisms are important for proper morphological and physiological transitions of streptomycete colonies, such as the onset of antibiotic production in stationary phase of growth. The genes for post-transcriptional modification of adenosine residue in

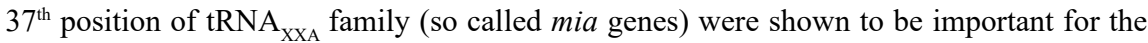
aforementioned processes, most likely because they impact tRNA ${ }_{\text {UAA }}^{\mathrm{Leu}}$ among other tRNAs. Our results were largely consistent with what is known about mia mutations in the other model systems, such as yeast and enterobacteria. Nevertheless, we also revealed several differences from the model systems, such as decreased susceptibility to hydrogen peroxide. This prompted us to look deeper into the behavior of the mia mutants, particularly their response to different stress factors. Here we report that $S$. albus mia mutants exhibit increased mistranslation rate as compared to their parental strain. These mutants are more susceptible than the parental strain to disulfide stress inducer diamide and DNA repair stressor caffeine. In summary, although the deficiency in certain tRNA modification appears to cause identical or very similar response (such as elevated mistranslation) across all so far studied bacterial systems, it also induces species- or genus-specific effects (such as disparate effects on $\mathrm{H}_{2} \mathrm{O}_{2}$ susceptibility). These differences could be attributed to the peculiarities of organization/ function of regulatory pathway governing the response to a given stress. The observed results are further discussed in the wider context of the role of tRNA modification pathway in bacterial biology.
\end{abstract}

Keywords: Streptomyces albus, tRNA, nonsense suppression assay, diamide, caffeine

Post-transcriptional tRNA modifications (PTTMs) have recently emerged as a novel and underappreciated layer of regulation of gene expression in pro- and eukaryotes [6]. One of the most general mechanisms by which PTTMs exert their biological effects hinges on unequal usage of synonymous codons and modification of their cognate tRNAs, leading to so called adaptive (codon-specific) translation. A good example of this phenomenon has recently been reported for Escherichia coli [13]. In this species proline codons ( $\mathrm{CCN})$ are decoded by three isoacceptor $\mathrm{tRNA}^{\text {Pro }}$, (tRNA $_{\mathrm{UGG}}$, $\mathrm{tRNA}_{\mathrm{GGG}}$, tRNA $\mathrm{CGG}_{\mathrm{C}}$ ) all of which carry methylated guanine residue in $37^{\text {th }}$ position of the tRNA ( $\mathrm{m}^{1} \mathrm{G} 37$; adjacent to anticodon loop which occupies positions 34-36). This PTTM is introduced into tRNA by SAM-dependent methyltransferase TrmD. The trmD null mutant cannot be generated, pointing to the essentiality of this PTTM. The fully modified tR$\mathrm{NA}_{\mathrm{UGG}}$ is capable of reading all proline codons, but loss of $\mathrm{m}^{1} \mathrm{G} 37$ specifically impairs reading of $\mathrm{CC}(\mathrm{C} / \mathrm{U})$, leading to frameshifts. Importantly, mRNAs for many membrane proteins responsible for active export of toxic substances are enriched with $\mathrm{CC}(\mathrm{C} / \mathrm{U})$ codon near start codons

(c) Ридкін О., Кошла О., Осташ Б., 2021 
[7]. Thus, knockdown of TrmD function renders $E$. coli highly sensitive to different antibiotics because of failure to produce respective efflux proteins. Hence, loss of certain PTTM may affect the translation of a subset of mRNAs, enriched with the codons that require modified tRNA (so called modification-tunable transcripts [1]).

The abundance and importance of adaptive translation in antibiotic-producing streptomycetes remains unknown. In related genus Mycobacterium, PTTM-related mechanisms play important role in response to oxidative stress [5]. Involvement of PTTM in some kind of regulation of stress responses appears to be a general theme across kingdoms, as studies of several eukaryotic models suggest $[3,4,8,15]$. We showed recently that knockouts of genes for hyper-

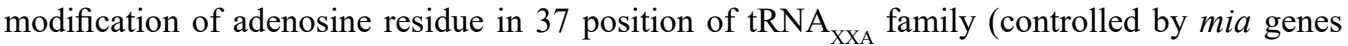
[16]) caused distinct changes in morphological and metabolic differentiation of Streptomyces [11, 17]. Nevertheless, the understanding of cause-to-consequence links between the mia mutations and the phenotypes in Streptomyces remain obscure. A body of circumstantial evidence supports our initial suggestion that effects of mia mutations are caused by impaired PTTM of tRNA ${ }^{\text {Leu }}$

(BldA). Yet there are also data portraying a wider impact of these mutation on Streptomyces tRNome [11], as well as data that run counter the established paradigm, such as decreased hydrogen peroxide susceptibility [12]. This makes harder to compare our data and interpret them in the wider context of what is known about biological roles of PTTMs in bacteria. We decided to address this uncertainty by asking as to whether mia mutants of $S$. albus exhibit some of the properties that are a hallmark of PTTM deficiency in the other bacterial systems. These include elevated mistranslation level and susceptibility to other types of chemical stresses. Our results reveal clear parallels between Streptomyces and other bacteria with the regard to the phenotypes being studied.

\section{Materials and Methods}

Strains and plasmids, used in this work, are listed in Table. Tryptic soy broth (Merck), oatmeal and soy-mannitol agars [9, 10] were used to grow Streptomyces (at $30{ }^{\circ} \mathrm{C}$ ) and plate matings. Escherichia coli strains were grown in liquid or agar LB medium, supplemented with appropriate antibiotic (if needed) at $37^{\circ} \mathrm{C}$. Genomic DNA from Streptomyces and plasmid DNA from E. coli were isolated using standard protocols [3]. Molecular biology enzymes were used according to recommendation of suppliers (Thermo).

Stop codon suppression tests were carried out with the help of plasmids pSETGUSTAG and pSETGUSTAG286. They are derivatives from plasmid pSETGUS, where the $2^{\text {nd }}$ and $286^{\text {th }}$ codons of gusA gene ORF, respectively, are replaced with TAG stop codon. Spectrophotometric analysis of $\beta$-glucuronidase activity of $g u s A^{+}$-strains was measured as described in [14]. Activity of GusA enzyme was calculated in Units/g. The rates of stop codon suppression are given in percentages, while the $\beta$-glucuronidase activities of respective pSETGUS $^{+}$-strains were taken as $100 \%$.

Disc diffusion assay of $S$. albus susceptibility to diamide was carried out as follows. Approximately $10^{7}$ spores of $\triangle \mathrm{miAB}$ or SAM2 were added to $15 \mathrm{~mL}$ of soft GYM [10] agar (1\%). The resulting mixture was overlaid onto Petri plates, containing $10 \mathrm{ml}$ of GYM medium (2\% agar). After solidification, disks with $10 \mu \mathrm{L}$ of $0.1 \mathrm{M}$ diamide were put on the surface of the test plates. The diameter of sterile zone was measured after $48 \mathrm{~h}$ of incubation at $30^{\circ} \mathrm{C}$. For the test of caffeine susceptibility, serial dilutions of liquid $S$. albus cultures (grown for $48 \mathrm{~h}$ in TSB) were plated on GYM medium with caffeine concentrations of $0 \mathrm{mM}, 5 \mathrm{mM}$, and $10 \mathrm{mM}$. The lawns of S. albus strains were plated under the same conditions. 


\begin{tabular}{|c|c|c|}
\hline \multicolumn{3}{|c|}{ Plasmids and bacterial strains, used in this work } \\
\hline Strain & Relevant characteristics & Source \\
\hline S. albus SAM2 & Derivative of J1074, deletion of pseudo att $^{\varphi \mathrm{C} 31}$ site & {$[2]$} \\
\hline S. albus $\triangle m i a A$ & Deletion of miaA (XNR_1074) in SAM2 & [11] \\
\hline S.albus $\Delta$ miaB & Deletion of miaB (XNR_1078) in SAM2 & [11] \\
\hline S. albus $\triangle$ mia $A B$ & Deletion of miaA and miaB in SAM2 & [12] \\
\hline E. coli ET12567 pUZ8002 & $\begin{array}{l}\text { Strain for conjugative transfer of coresident plasmids; dam-13::Tn9 } \\
d c m-6 h s d M \text {; harbors conjugative plasmid pUZ8002; } \mathrm{Cm}^{\mathrm{R}}, \mathrm{Km}^{\mathrm{R}}\end{array}$ & [9] \\
\hline pSETGUS & $\begin{array}{l}\varphi \mathrm{C} 31 \text {-based vector carrying gus } A \text { fusion to thiostrepton-inducible promoter } \\
\text { tipAp; } \mathrm{Am}^{\mathrm{R}}\end{array}$ & {$[14]$} \\
\hline pSETGUSTAG & pSETGUS with TAG codon in second position of the gene $g u s A ; \mathrm{Am}^{\mathrm{R}}$ & {$[14]$} \\
\hline $\begin{array}{l}\text { pSETGUSTAG } 286 \\
\mathrm{Cm}^{\mathrm{R}}-\text { resistance to chloran }\end{array}$ & $\begin{array}{l}\text { pSETGUS with TAG codon in } 286^{\text {th }} \text { position of gus } A \text { gene; } \mathrm{Am}^{\mathrm{R}} \\
\text { mphenicol, } \mathrm{Km}^{\mathrm{R}}-\text { to kanamycin, } \mathrm{Am}^{\mathrm{R}}-\text { to apramycin }\end{array}$ & {$[14]$} \\
\hline
\end{tabular}

\section{Results and Discussion}

Mistranslation of stop codons is elevated in mia mutants of $S$. albus, as compared to the parental strain. We used two reporter constructs to elucidate the influence of mia mutations on mistranslation. Plasmids pSETGUSTAG and pSETGUSTAG286, both containing stop codon TAG in gusA gene ORF, as well as control plasmid pSETGUS, with unchanged gusA, were used. Schemes of the above mentioned gusA fusion constructs are shown on Fig. 1.

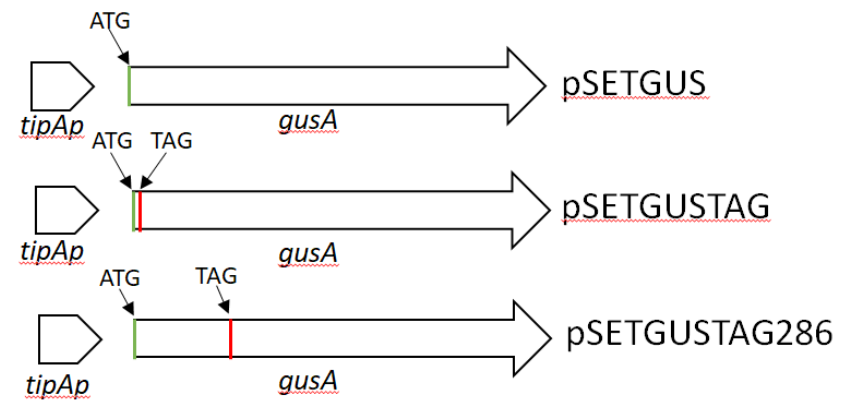

Fig. 1. Schemes of gus $A$ constructs in plasmids pSETGUS, pSETGUSTAG and pSETGUSTAG286. tip $A p$ - thiostrepton-inducible promoter; gus $A$ - $\beta$-glucuronidase gene; ATG - start codon in gusA ORF; TAG - stop codon, introduced in $2^{\text {nd }}$ and $286^{\text {th }}$ position of gusA ORF, respectively

S. albus parental strain (SAM2) and its mia mutants, individually carrying each of the aforementioned plasmids, were generated. GusA activity was measured at $48 \mathrm{~h}$ of growth in $\mathrm{TSB}$, as described in Methods. We noticed elevated levels of $\beta$-glucuronidase activity for some of the mia mutants, containing TAG-versions of gusA gene, compared to the respective SAM2 strains. We calculated the rates of TAG-codon suppression in pSETGUSTAG- and pSETGUSTAG286-containing mia mutants and SAM2. Results are summarized in Fig. 2 and given in percentages, for every case the GusA-activity of respective pSETGUS ${ }^{+}$-strains is taken as $100 \%$. Mutant $\triangle$ mia $A B$, carrying the plasmid pSETGUSTAG, as well as $\triangle m i a A$ with plasmid pSETGUSTAG286, demonstrated higher rates of stop codon misreading, as compared to controls. An increased stop codon readthrough could be explained by elevated translational infidelity, described previously for some mia mutants. We have also noticed that the position of TAG codon in ORF of gusA gene affected the level of suppression. Thus, for $\triangle$ miaAB strain TAG suppression is more prominent if the stop codon is in $2^{\text {nd }}$ position rather than $286^{\text {th }}$, while for $\triangle m i a A$ mutant the opposite effect was observed. It was already shown by us that $\triangle$ miaAB and $\triangle$ miaA mutants differ in the degree of the mutant phenotypes [12]. 

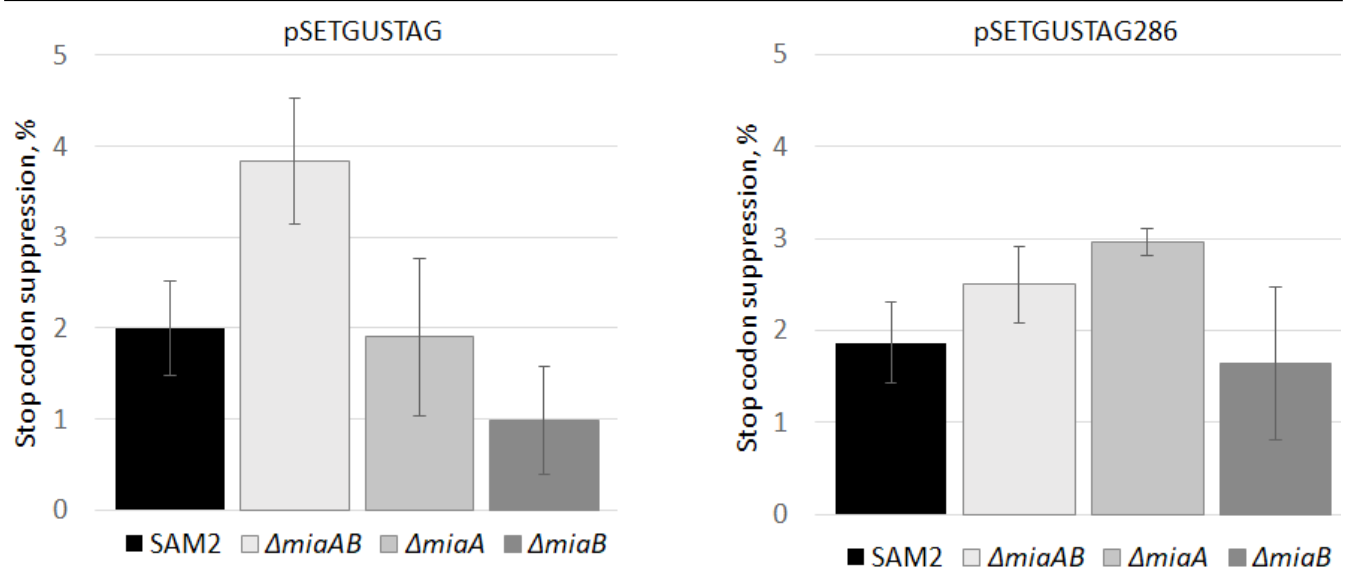

Fig. 2. Rates of stop codon suppression for $S$. albus SAM2, $\triangle m i a A B, \triangle m i a A$ and $\triangle m i a B$ strains. pSETGUSTAG carries stop codon in $2^{\text {nd }}$ and pSETGUSTAG286 - in $286^{\text {th }}$ position of the gene gusA. Percentages are calculated against respective pSETGUS $^{+}$strains. Represented results are given as mean values of three repeats with standard errors

The mia mutants exhibited sensitivity towards caffeine and diamide. Diamide is known as a powerful oxidant of thiols in proteins. Caffeine is a purine alkaloid used worldwide. It is quite toxic compound and can cause DNA damage in microorganisms. We used two tests to observe mia mutants' response to this kind of chemical stresses. Susceptibility to diamide was tested using paper disks with $10 \mu \mathrm{L}$ of $0.1 \mathrm{M}$ solution, as described in Methods. The result of this assay is summarized in Fig. 3. Our data demonstrates that $\triangle$ miaAB strain is more susceptible to diamide than the control strain SAM2.

$$
30
$$

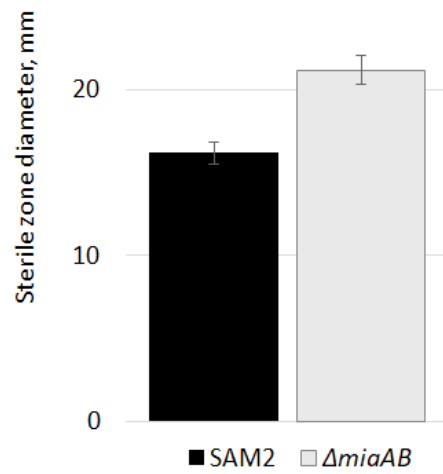

Fig. 3. Diameters of S. albus growth inhibition zones (in mm), caused by $10 \mu \mathrm{L}$ of $0,1 \mathrm{M}$ diamide. SAM2 $S$. albus SAM2, $\triangle m i a A B$-S. albus $\triangle$ miaAB. Results represent the mean values of 11 repeats, error bars are standard error

The next assay was performed to test susceptibility to caffeine. We plated $S$. albus strains on GYM medium, supplemented with $5 \mathrm{mM}$ and $10 \mathrm{mM}$ of caffeine. For the spot test, strains were grown in liquid TSB for $48 \mathrm{~h}$ and $10 \mu \mathrm{L}$ of cultures, together with the same amounts of $10^{-4}, 10^{-5}$ and $10^{-6}$ dilutions, were plated and incubated for $48 \mathrm{~h}$, as it is shown on Fig. 4, A. As we can see, increased concentration of caffeine has negative effects on the growth of all S. albus 
strains. With approximately equal concentration of CFUs in $1 \mathrm{~mL}$ of culture for SAM2, $\triangle$ miaA and $\triangle$ miaAB, only SAM2 showed visible growth on $10^{-4}$ dilution on $10 \mathrm{mM}$ caffeine. For the lawns cultivation, results were similar (Fig. 4, B). Caffeine had negative effect on all strains, but $\triangle m i a A$ and $\triangle m i a A B$ showed a considerable delay in vegetative and aerial mycelium formation in presence of $5 \mathrm{mM}$ and $10 \mathrm{mM}$ caffeine, in comparison to control strain SAM2.

A w/o caffeine $5 \mathrm{mM}$

$10 \mathrm{mM}$

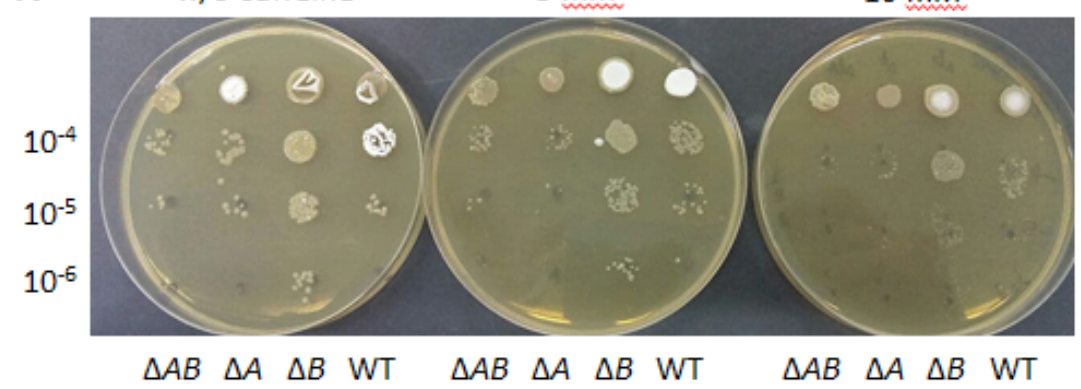

B
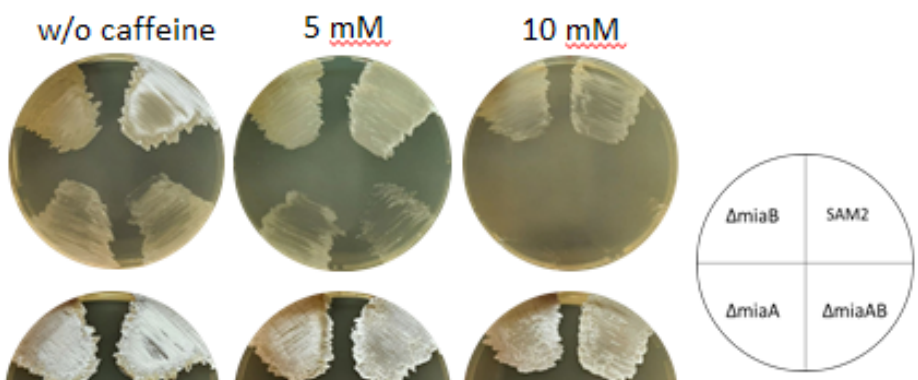

$72 \mathrm{~h}$
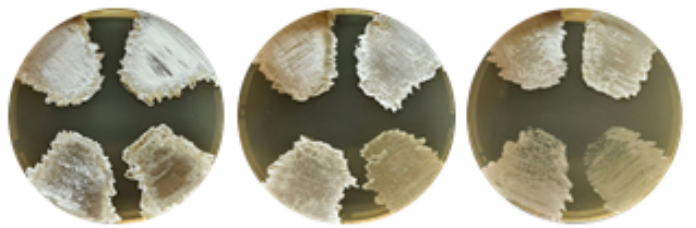

Fig. 4. Susceptibility of $S$. albus strains to caffeine. A. Liquid TSB cultures of $S$. albus SAM2, $\Delta$ miaAB, $\triangle m i a A$ and $\triangle m i a B$ were spotted on GYM medium, supplemented with $5 \mathrm{mM}$ and $10 \mathrm{mM}$ of caffeine. Plates were incubated for $72 \mathrm{~h}$ before taking pictures. Numbers to the left label serial dilutions. $\mathbf{B}$. $S$. albus strains were plated on GYM medium, supplemented with $5 \mathrm{mM}$ and $10 \mathrm{mM}$ of caffeine, as it is shown on scheme to the right. Photos were taken on $24 \mathrm{~h}$ and $72 \mathrm{~h}$ of growth

The delay was especially pronounced at $24 \mathrm{~h}$. On the first day of growth on $10 \mathrm{mM}$ caffeine $\triangle m i a A$ and $\triangle m i a A B$ strains were unable to form vegetative mycelium, but $\triangle m i a B$ and SAM2 exhibited more abundant growth. Strain $\triangle$ miaA formed aerial mycelium on $72 \mathrm{~h}$ day of growth only on medium without caffeine. The strain with deletion of both miaA and miaB genes showed the highest susceptibility to caffeine. Mutant with miaB deletion showed the level of susceptibility to caffeine similar to that of the parental SAM2. We assume, therefore, that deletion of miaA gene in $S$. albus results in higher sensitivity to caffeine, and additional deletion of miaB pronounces this effect.

We report that mia mutations in Streptomyces impact translation fidelity and susceptibility to different stressors. Considering our data and the fact that Mia proteins modify a large set of tRNAs, we assume that codon mistranslation in S. albus depends not only on the position and nature of the codon, but also on the other unique features of the dynamic translational machinery. Results of bioassays show that deletion of miaA is the main reason of mistranslation and higher susceptibility to caffeine and diamide. As one can see, $\Delta m i a B$ strain did not display elevated mis- 
translation rate under our experimental conditions, and also this strain showed similar phenotype to the parental strains while growing on caffeine-supplemented GYM agar. Probably, miaB plays less important role in the response to studied stressors, as opposed to miaA. Indeed, posttranscriptional modifications of tRNA affect bacterial homeostasis and, since for Streptomyces there is a little information about mia-dependent pathways, it is our goal to elucidate this issue deeper.

Acknowledgements. We thank Prof. A. Luzhetskyy (Saarbrucken University, Germany) for providing us with the plasmids pSETGUSTAG and pSETGUSTAG286. B.O. was supported by the grant BG-80F from Ministry of Education and Science of Ukraine.

\section{REFERENCES}

1. Aubee J. I., Olu M., Thompson K. M. TrmL and TusA are necessary for $r p o S$ and MiaA is required for $h f q$ expression in Escherichia coli // Biomolecules. 2017. Vol. 7. P. 39. doi: 10.3390/biom7020039.

2. Bilyk B., Luzhetskyy A. Unusual site-specific DNA integration into the highly active pseudoattB of the Streptomyces albus J1074 genome // Appl. Microbiol. Biotechnol. 2014. Vol. 98. P. 5095-104. doi: 10.1007/s00253-014-5605-y.

3. Candiracci J., Migeot V., Chionh Y. H. et al. Reciprocal regulation of TORC signaling and tRNA modifications by Elongator enforces nutrient-dependent cell fate // Sci. Adv. 2019. Vol. 5. P. eaav0184. doi: 10.1126/sciadv.aav0184.

4. Chan C., Pham P., Dedon P. C., Begley T. J. Lifestyle modifications: coordinating the tRNA epitranscriptome with codon bias to adapt translation during stress responses // Genome Biol. 2018. Vol. 19. P. 228. doi: 10.1186/s13059-018-1611-1.

5. Chionh Y. H., McBee M., Babu I. R. et al. tRNA-mediated codon-biased translation in mycobacterial hypoxic persistence // Nat. Commun. 2016. Vol. 7. P. 13302. doi: 10.1038/ ncomms 13302 .

6. Edwards A. M., Addo M. A., Dos Santos P. C. Extracurricular functions of tRNA modifications in microorganisms // Genes. 2020. Vol. 11. P. 907. doi: 10.3390/genes11080907.

7. Hou Y. M., Masuda I., Foster L. J. tRNA methylation: An unexpected link to bacterial resistance and persistence to antibiotics and beyond// Wiley Interdiscip. Rev. RNA. 2020. Vol. 11. P. e1609. doi: 10.1002/wrna.1609.

8. Huber S. M., Leonardi A., Dedon P. C., Begley T. J. The versatile roles of the tRNA epitranscriptome during cellular responses to toxic exposures and environmental stress // Toxics. 2019. Vol. 7. P. 17. doi: 10.3390/toxics7010017.

9. Kieser T., Bibb M., Buttner M. et al. Practical Streptomyces genetics. Norwich: John Innes Foundation. 2000. 634 p.

10. Koshla O., Lopatniuk M., Rokytskyy I. et al. Properties of Streptomyces albus J1074 mutant deficient in tRNA(Leu)(UAA) gene bldA // Arch. Microbiol. 2017. Vol. 199. P. 1175-83.

11. Koshla O., Yushchuk O., Ostash I. et al. Gene miaA for post-transcriptional modification of tRNA ${ }_{\mathrm{XXA}}$ is important for morphological and metabolic differentiation in Streptomyces // Mol. Microbiol. 2019. Vol. 112. P. 249-265. doi: 10.1111/mmi.14266.

12. Koshla O., Kravets V., Dacyuk Y. et al. Genetic analysis of Streptomyces albus J1074 mia mutants suggests complex relationships between post-transcriptional tRNA $\mathrm{XXA}_{\text {modifications }}$ and physiological traits // Folia Microbiol. 2020. Vol. 65.

13. Masuda I., Matsubara R., Christian T. et al. tRNA methylation is a global determinant of bacterial multi-drug resistance // Cell Syst. 2019. Vol. 8. P. 302-314.e8. doi: 10.1016/j. cels.2019.03.008. 
$\overline{\text { 14. Myronovskyi M., Welle E., Fedorenko V., Luzhetskyy A. Beta-glucuronidase as a sensitive and }}$ versatile reporter in actinomycetes // Appl. Environ. Microbiol. 2011. Vol. 77. P. 5370-5383. doi:10.1128/AEM.00434-11.

15. Nagaraja S., Cai M. W., Sun J. et al. Queuine is a nutritional regulator of Entamoeba histolytica response to oxidative stress and a virulence attenuator // mBio. 2021. Vol. 12. P. e03549-20. doi: 10.1128/mBio.03549-20.

16. Schweizer U., Bohleber S., Fradejas-Villar N. The modified base isopentenyladenosine and its derivatives in tRNA // RNA Biol. 2017. Vol. 14. P. 1197-1208. doi: 10.1080/15476286.2017.1294309.

17. Sehin Y., Koshla O., Dacyuk Y. et al. Gene ssfg_01967 (miaB) for tRNA modification influences morphogenesis and moenomycin biosynthesis in Streptomyces ghanaensis ATCC14672 // Microbiology. 2019. Vol. 165. P. 233-245.

Стаття надійшла до редакиії 24.05.21

доопрачьована 26.05.21

прийнята до друку 01.06.21

\title{
MIA МУТАНТИ STREPTOMES ALBUS J1074 СХИЛЬНІ ДО ПОМИЛОК У ПРОЦЕСІ ТРАНСЛЯЦЇ̈ ТА ПІДВИЩЕНОЇ ЧУТЛИВОСТІ ДО СТРЕСОВИХ ЧИННИКІВ
}

\author{
О. Ридкін, О. Кошла, Б. Осташ* \\ Львівський національний університет імені Івана Франка \\ вул. Грушевського, 4, Львів 79005, Украӥна \\ e-mail: bohdan.ostash@lnu.edu.ua
}

Streptomyces albus J1074 використаний нами як зручна модель для вивчення різних аспектів tRNA ${ }_{\text {UAA }}^{\text {Leu }}$-залежних регуляторних механізмів, притаманних представникам роду Streptomyces. Ці механізми важливі для належного перебігу морфологічних і фізіологічних змін у колоніях стрептоміцетів, таких як початок продукції антибіотиків протягом стаціонарної фази росту. Показано, що гени посттранскрипційної модифікації залишку аденозину в 37-й позиції родини тРНК 3 антикодоном XXA (т. зв. гени mia) є важливими для вищезазначених процесів, швидше за все, тому, що спричинюють найсильніший вплив на $\operatorname{RRNA}_{\mathrm{UAA}}^{\mathrm{Leu}}$. Наші результати значною мірою узгоджуються 3 тим, що відомо про тіa мутації в інших модельних об'єктах, таких як дріжджі й ентеробактерії. Тим не менше, ми також виявили кілька відмінностей, зокрема, зниження сприйнятливості до перекису водню. Це спонукало нас глибше вивчити властивості mia мутантів, особливо їхню реакцію на різні стресові фактори. Виявлено, що тіa мутанти S. albus демонструють підвищений рівень супресії стоп-кодону TAG, порівняно з батьківським штамом. Ці мутанти $є$ чутливішими до індуктора дисульфідного стресу діаміду та до кофеїну, що пошкоджує механізми репарації ДНК. У підсумку, відсутність певної модифікації тРНК, найвірогідніше, спричиняє однакову чи дуже подібну відповідь у всіх досліджуваних бактерій (наприклад, підвищення рівнів помилок під час трансляціі), проте і викликає специфічні для виду чи роду ефекти (наприклад, різний вплив на чутливість до $\mathrm{H}_{2} \mathrm{O}_{2}$ ). Ці відмінності можна пояснити особливостями організації/функції регуляторного шляху, що координує відповідь на певний стресовий фактор. Отримані результати обговорено в ширшому контексті ролі модифікацій тРНК у біології бактерій.

Ключові слова: Streptomyces albus, тРНК, тест на супресію нонсенс-мутацій, діамід, кофеїн 